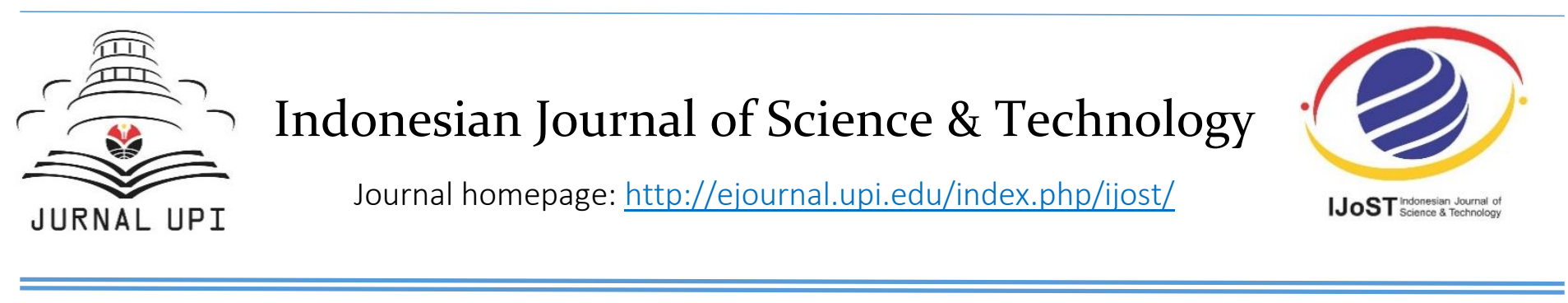

\title{
Application of Plants Extracts as Green Corrosion Inhibitors for Steel in Concrete - A review
}

\author{
Yuli Panca Asmara ${ }^{2}$, , Tedi Kurniawan ${ }^{1}$, Agus Geter Edy Sutjipto³, Jamiluddin Jafar ${ }^{1}$ \\ ${ }^{1}$ Faculty of Mechanical Engineering, Universiti Malaysia Pahang, Pekan, 26600, Pahang, Malaysia \\ ${ }^{2}$ Faculty of Mechanical Engineering, University Mataram, Jalan Majapahit No.62, Gomong, Selaparang, 83115, \\ Mataram, Nusa Tenggara Barat, Indonesia \\ ${ }^{3}$ Faculty of Science and Technology Industry, Universiti Malaysia Pahang, Gambang, 26300, Pahang, Malaysia
}

Correspondence: E-mail: ypanca@hotmail.com

\section{ABSTRACT}

High requirements in protection of steel reinforcing bar (steel rebar) from corrosion are necessary since there are multi interaction of corrosive chemicals which cause early damage of concrete buildings. Corrosion of steel in concrete can destroy the concretes and reduce concrete strength. To protect rebar from corrosion, application of corrosion inhibitor is believed to have higher performance compared to other protection systems. To date, organic inhibitors have promising methods in steel rebar protection as they are environment-friendly, compatible with concrete, cost effective and applicable in any various concrete conditions. Thus, demands in using these inhibitors tend to increase significantly. This paper reviews the applications of green corrosion inhibitor specifically highlighted in protecting mechanisms, typical plants extracted, performance in corrosion protection, and classification of green corrosion inhibitors. The corrosion resistances of carbon steels in concrete protected by green inhibitors are in focus. As summary, it can be confidently notified that green corrosion inhibitors for steel in concrete will have a prospect to be used as corrosion prevention in the future with further improvements.

(c) 2018 Tim Pengembang Jurnal UPI
ARTICLE INFO

Article History:

Submitted/Received 16 May 2018 First Revised $17 \mathrm{Jul} 2018$

Accepted 25 Aug 2018

First Available online 28 Aug 2018

Publication Date 01 Sep 2018

\section{Keywords:}

Green inhibitor,

plant extract,

corrosion,

steel rebar,

concrete. 


\section{INTRODUCTION}

Corrosion in steel rebar is one of the most factors which causes damages on concrete structures. Rebar has serious corrosion problems when they are contacted with water, salt $(\mathrm{NaCl})$ and carbon dioxide $\left(\mathrm{CO}_{2}\right)$. In industrial areas where $\mathrm{CO}_{2}, \mathrm{H}_{2} \mathrm{~S}, \mathrm{~S}$ and $\mathrm{C}$ are present, corrosive species are more complex which complicate corrosion mechanism (Asmara et al., 2016; Alia et al., 2017; Asmara et al., 2013; Asmara et al., 2011). Corrosion of rebar does not only damage concretes but also reduces concrete strength. Typical corrosion forms on rebar are uniform corrosion, galvanic and pitting corrosion. Vermany (Vermany et al., 1985; Jenifer et al., 2000) reported that at the year of 1997, it was estimated that among 580,000 concrete bridges in the United States, there was structurally deficient of 100.000. The cost to repair these bridge deficiencies was estimated to be ranging from $\$ 78$ billion to $\$ 112$ billion. Thus, the need to manage corrosion protection on rebar has been an important element in designing concrete structures

To provide long-term life service, integrated approaches in selecting an appropriate material to protect rebar from corrosion are required. Among the various protection methods, applying inhibitors mixed in concrete is believed to have more advantages. To avoid environmental issue, green corrosion inhibitors have become one main promising key. These types of inhibitors are not hazardous to environments, compatible with any type concretes and economically affordable. Accordingly, research studies on green corrosion inhibitors are growing fast. The beneficial properties of green inhibitors or socalled organic inhibitors are environmentfriendly and biodegradable (Asmara et al., 2016; Sangeetha et al., 2011). Green corrosion inhibitors are commonly made of extracts of natural plants which are abundantly available in many countries. Most of green inhibitors commonly contain $\mathrm{P}, \mathrm{N}, \mathrm{S}, \mathrm{O}$. These atoms coordinate with metals ions to form protective films formed on the metal surface to inhibit further corrosion process (Sangeetha et al., 2011). The other mechanism proposed by Amitha et al (Amitha et al., 2012) is that cation of onium is adsorbed on the cathodic sites of the metal surface to block the corrosion reaction. In further explanations, they suggested some inhibition mechanism which are adsorption on metal surface, change anodic and/or cathodic reaction, interfere diffusion rate, and decreasing the electrical resistance (Amitha et al., 2012).

\section{CORROSION ON REBAR}

Corrosion on rebar occurs when concretes expose to severe environments such as high acidity, high $\mathrm{CO}_{2}$ contents, and high humidity environments (Asmara et al., 2016). Concretes which have high pH (about 12-13) tend form passive film to the reinforcing steel surface. In this condition, steel is in corrosion resistant condition (Bentur et al., 1997). However, pH may decrease when corrosive species penetrate to the concrete pores. Corrosive species such as $\mathrm{CO}_{2}, \mathrm{H}_{2} \mathrm{~S}$ and chlorides which ingress through concrete pores will react with reinforcing steels bar resulting in corrosion to the steel. Corrosion products in the form of ferric oxides/hydroxides will expand volume of steels to 3-6 times than the volume of original steel which can induce crack to the concretes (Kumar \& Quraishi, 2013; Asmara et al., 2017). Durability of the rebar depends on several factors such as temperature, ratio of cement/water, $\mathrm{pH}$, humidity, quality of cement or concrete composition, and environmental effects. In marine conditions which represent corrosive environments, chloride ions are the most aggressive corrosion agents as these ions are able to decrease concrete $\mathrm{pH}$. Chlorides ions have the ability to bond with cement to form Friedel's salt $\left(\mathrm{Ca}_{2} \mathrm{Al}(\mathrm{OH})_{6} \mathrm{Cl} \cdot 2 \mathrm{H}_{2} \mathrm{O}\right.$, or $\left.\mathrm{C}_{3} \mathrm{~A} \cdot \mathrm{CaCl}_{2} \cdot 1 \mathrm{OH}\right)$ which reduce concrete strength (James, 2004). Thus, the concentration of chlorides

DOI: http://dx.doi.org/10.17509/ijost.v3i2.12760 | p- ISSN 2528-1410 e- ISSN 2527-8045 | 
ions allowed in the concrete mixture are important parameters which should be considered in order to obtain durable concrete structures. Critical chloride threshold (CCTL) in concrete is defined as the minimum concentration of chloride in the concrete which causes concrete is in active (pitting) corrosion for the reinforcing steel. The other definition of CCTL is the chloride content at which causes current density exceeded $10 \mu \mathrm{A} \cdot \mathrm{cm}^{-2}$ for 5 hours (Hurley, 2006).

\section{CORROSION MECHANISM OF STEEL REBAR}

Several researchers proposed mechanism of steel corrosion in concrete (Shahid, 2011; Jae et al., 2016; Cabrini et al., 2015; Elsener, 2001; Söylev, 2008; Ormellese et al., 2006; Page, 1975; Hausmann, 1967; Gouda, 1970; Valcarce, 2008; Freire, et al., 2009; Cabrini, 2002; Asma et al., 2011). All agree that corrosion on rebar is influenced by properties of concretes. Structure of concrete which is porous can be easily penetrated by water and acidic ions. Ions, typically chlorides cause depassivation of the protective films lead to corrosion process. Process corrosion on rebar can be simplified by the following reactions (Asmara et al., 2011; Magdalena, 2016):

In anodic site, there is reaction oxidation process on steel (Asmara et al., 2013; Asmara, 2011).

$\mathrm{Fe}^{0} \rightarrow \mathrm{Fe}^{2+}+2 \mathrm{e}$

when steel reacts with water, pits will grow starting from anodic oxidation of steel to produce hexaaquo iron (II) (Sastri et al., 2011).

$\mathrm{Fe}^{2+}+6 \mathrm{H}_{2} \mathrm{O} \rightarrow \mathrm{Fe}\left(\mathrm{H}_{2} \mathrm{O}\right)_{6}{ }^{2+}$

$\left[\mathrm{Fe}(\mathrm{H} 2 \mathrm{O})_{6}\right]^{2+} \rightarrow\left[\mathrm{Fe}(\mathrm{OH})\left(\mathrm{H}_{2} \mathrm{O}\right)_{5}\right]^{+}+\mathrm{H}^{+}$

$\left[\mathrm{Fe}(\mathrm{OH})(\mathrm{H} 2 \mathrm{O})_{5}\right]^{+} \rightarrow \mathrm{Fe}(\mathrm{OH})_{2}+4 \mathrm{H}_{2} \mathrm{O}+\mathrm{H}^{+}$
In the presence of oxygen/chloride ions $\mathrm{Fe}^{2+}$ will hydrate to form ferric oxide $\mathrm{FeO} \cdot \mathrm{OH}$ which follows this reaction.

$2 \mathrm{Fe}(\mathrm{OH})_{2}+1 / 2 \mathrm{O}_{2} \rightarrow 2 \gamma-\mathrm{FeOOH}+\mathrm{H}_{2} \mathrm{O}$

Another expression for chemical reaction of steel in concrete is presented by A. Rosenberg as (Rosenberg \& Andrade, 1989):

$x \mathrm{Fe}^{2+}+\mathrm{yO}_{2}+\mathrm{H}_{2} \mathrm{O} \rightarrow \mathrm{Fe}_{3} \mathrm{O}_{4}$, $\mathrm{Fe}\left(\mathrm{OH}_{3}\right), \mathrm{Fe}\left(\mathrm{OH}_{3}\right) \cdot 3 \mathrm{H}_{2} \mathrm{O}$

Combinations of corrosive ions or species cause corrosion processes involving both physico-chemical and electrochemical reactions. The reactions locate on cathodic site. It consumes electrons and increase corrosion rate.

$\mathrm{O}_{2}+2 \mathrm{H}_{2} \mathrm{O}+4 \mathrm{e} \rightarrow 4 \mathrm{OH}^{-}$

$2 \mathrm{H}^{+}+2 \mathrm{e} \rightarrow \mathrm{H}_{2}$

Product of reaction such as ions $\mathrm{OH}^{-}$will form ferro-hydroxide which is soluble in aqueous media. Concrete, typically, has high $\mathrm{pH}$ and tend to form passive layer of $\mathrm{Fe}_{2} \mathrm{O}_{3}$ on the steel surface. Increasing number of ions $\mathrm{OH}^{-}$in concrete, create very high $\mathrm{pH}$ causes reducing integrity of rebar strength.

Steps of corrosion process in concretes can be summarized as follows: firstly, corrosive ions penetration of oxide film by chloride ion, competition between adsorption and passivating of ions, and finally oxidising the steel rebar. The other reactions are catalysis of corrosion reaction by creating bridging structure and forming complex compound between ions and steels (Gaidis, 2004) 
161 | Indonesian Journal of Science \& Technology, Volume 3 Issue 2, September 2018 Hal 158-170

Tabel 1. Critical Chloride Threshold Level values of the different reinforcing metals in concrete

\begin{tabular}{|c|c|c|c|c|}
\hline Types of Metals & Concrete conditions & $\begin{array}{l}\text { Threshold } \\
\text { concentration }\end{array}$ & $\begin{array}{l}\text { Corrosive specimen } \\
\text { method investigation }\end{array}$ & Ref. \\
\hline Carbon steel & $\begin{array}{l}\text { Mortar suspensions } \\
\text { OPC }\end{array}$ & $2.4 \%$ & Anodic polarisation & (Ggouda, 1970) \\
\hline SS & OPC solution & $4 \%$ & Corrosion rate & $\begin{array}{l}\text { (Garcia et al., } \\
\text { 2007) }\end{array}$ \\
\hline Alloy 254 SMO & OPC solution & $10 \%$ & Corrosion rate & (Bertolini, 2007) \\
\hline Galvanised Zinc & OPC solution & $1.5 \mathrm{Kg} / \mathrm{m}^{3}$ & Corrosion rate & $\begin{array}{l}\text { (Darwin et al., } \\
\text { 1974) }\end{array}$ \\
\hline 304 L SS & OPC solution & $4 \%(W)$ & Anodic polarisation & (Hurley, 2006) \\
\hline 316 L SS & OPC solution & $5.5 \%(W)$ & Anodic polarisation & (Hurley, 2006) \\
\hline LDX 2101 Duplex SS & OPC solution & $6.5 \%-7 \%(W)$ & Anodic polarisation & (Hurley, 2006) \\
\hline Carbon steel & $\begin{array}{l}\text { Concrete slabs with } \\
\text { added Clto various expo- } \\
\text { sure conditions } \\
\text { OPC }\end{array}$ & $0.1-0.19$ & $\begin{array}{l}\text { Corrosion rate, visual } \\
\text { inspection, mass loss }\end{array}$ & (Hope, 1987) \\
\hline Carbon steel & $\begin{array}{l}\text { Cements with high or low } \\
\text { alkali content; Mortars } \\
80 \% \text { RH } 100 \% \text { RH }\end{array}$ & $\begin{array}{l}0.6-1.8 \\
0.5-1.7\end{array}$ & Corrosion rate & (Petterson, 1994) \\
\hline
\end{tabular}

4. GREEN CORROSION INHIBITOR FOR STEEL REBAR

\subsection{Inhibitor}

A corrosion inhibitor is a chemical compound which is added in small quantity in solutions or gas can reduce corrosion rate of metals or alloys. Performances of inhibitors are indicated by effectiveness which is percentage of corrosion rate reduction. Corrosion inhibitor reduces corrosion rate by formation of a film which inhibit corrosion process in the metal surface. The other mechanism is by increasing solution resistivity of the solutions to reduce corrosion rate. Based on protection mechanisms, there are three types of corrosion inhibitors. The first, inhibitors which work by polarise corrosion potential on anodic region called anodic inhibitor. Anodic inhibitors passivate by forming film on the metals surface to reduce corrosion rate. Examples of anodic inhibitors are chromates, nitrates, molybdates, and tungstate. Secondly cathodic inhibitors which are inhibitors acting by polarising corrosion potential to cathodic regions. They limit corrosive species through diffusion process. The last are corrosion inhibitors which act by combining both anodic and cathodic mechanism. Corrosion inhibitors are also can be classified as chemicals or natural and organic or inorganic. Generally, the inorganic inhibitors have mechanism of cathodic and anodic polarisation. While organics inhibitors work by absorption mechanism to form film on the metal surface.

\subsection{Green Inhibitor}

Green corrosion inhibitors are inhibitors made by extracting plants for corrosion prevention. These inhibitors have become priority for researchers as it is proposed to replace application of chemicals inhibitors which are environmentally hazardous substances. Researches on green corrosion inhibitors have shown increasingly as green inhibitors are safe, biodegradable and environmentally friendly. Green inhibitors also could be found or produced easily. There are many researchers have been conducted to investigate these 
natural resources over the years. Delonix regia used rosemary leaves as green inhibitor to protect aluminium in hydrochloric acid solutions (Abiola et al., 2007). Hazwan investigated natural oil palm as a corrosion inhibitor for mild steel. Hazwan et al., (2016) showed the inhibition of corrosion with ethanolic extract of African bush pepper (Piper guinensis) on mild steel.

Inhibitors from black pepper extracted and nicotine have been studied by Quraishi et al., (2009) and showed best performances. They studied corrosion inhibition of mild steel in hydrochloric solution by black pepper extract (Piper nigrum family: piperaceae) by mass loss measurements, potentiodynamic polarisation, and electrochemical impedance spectroscopy (EIS). Black pepper extract gave maximum inhibition efficiency (98\%) at $120 \mathrm{ppm}$ at $35^{\circ} \mathrm{C}$ for mild steel in hydrochloric acid medium. Electrochemical evaluation revealed it to be a mixed-type inhibitor and that charge transfer controls the corrosion process (Ebenso et al., 2004).

The corrosion inhibition property was attributed to an alkaloid "piperine". Nicotine is an organic compound belonging to the alkaloids: a liquid, oily, and colorless derivative of the ortinina. This organic compound is a candidate for the protection of petroleum pipeline systems, since it is of natural origin, readily found in tobacco plants (nicotiana tabacum), in which it is the major active chemical component. Furthermore, the nicotiana tabacum extract has been reported (Njokua et al., 2013). They demonstrated that the best concentration was $1200 \mathrm{mg} / \mathrm{L}$ with 89\% efficiency and Bhawsar et al., (2009) found to have inhibitory corrosion properties for mild steel in acidic medium, attaining $94.13 \%$ IE at an optimum concentration of $10 \mathrm{~g} / \mathrm{L}$ under static conditions for 6 hours at $303^{\circ} \mathrm{K}$. As summary,
Table 2. reviews of discussion the development of green inhibitor for various metals.

\subsection{Current researchs on green inhibitor for steel rebar}

Green corrosion inhibitor is an inhibitor made of organic substance or plant extracted. The inhibitor is able to form a protective layer to prevent ingress of aggressive species like oxygen, carbon-di-oxide, sulfate, chloride, and moisture. In reinforcement corrosion, many researchers have conducted various experimental works to improve inhibitor's efficiency. Their effectiveness of inhibitor depends on the property of their chemical constituents. Role of inhibitor to extent service life of steel on concrete have shown improvements. The following are presented literature surveys of various organic constituents used to produce green inhibitor. The following researchers presented comprehensive reviews of extract plants to inhibit corrosion process of rebar.

Quraishi et al., (2012) in the present investigation, studied effects of calcium palmitate alone and in combination with calcium nitrite on corrosion of steel in concrete. The results of the investigation demonstrated that calcium palmitate showed an effective inhibitor. Inhibitor provided $91 \%$ to $92 \%$ efficiency after 90 days of exposure time in $3.5 \% \mathrm{NaCl}$ solution. It was shown that the inhibitor did not have effects on the mechanical strength of cement and concrete. Petrographic examination revealed that calcium palmitate blocs the pores and reduced the corrosion rate of steel. Further investigation, they found that calcium palmitate inhibited corrosion though adsorption mechanism. Inhibitor created film to the steel surface through polar carboxylate group blocking the pores forming insoluble hydrophobic ferric stearate salt. 
163 Indonesian Journal of Science \& Technology, Volume 3 Issue 2, September 2018 Hal 158-170

Tabel 2. Green corrosion inhibitors for any metals and mechanism

\begin{tabular}{|c|c|c|c|c|c|}
\hline $\begin{array}{l}\text { Plants Ex- } \\
\text { tract }\end{array}$ & Elements & Protection mechanism & Metal & $\begin{array}{l}\text { Solu- } \\
\text { tions }\end{array}$ & Ref. \\
\hline $\begin{array}{l}\text { Argemone } \\
\text { mexicana }\end{array}$ & alkaloid & $\begin{array}{l}\text { The free electrons on the } \mathrm{O} \text { and } \mathrm{N} \text { atoms } \\
\text { form bonds with the electrons on the } \\
\text { metal surface. } \mathrm{O} \text { atom helps to free an } \\
\text { electron on the } \mathrm{N} \text { atom and forms a } \\
\text { stronger bond with the metallic elec- } \\
\text { trons. }\end{array}$ & & & $\begin{array}{l}\text { (Amitha et al., } \\
\text { 2012) }\end{array}$ \\
\hline Garlic & $\begin{array}{l}\text { allyl propyl di- } \\
\text { sulphide }\end{array}$ & $\begin{array}{l}\text { Affects the potential cathodic process of } \\
\text { steel. }\end{array}$ & & & $\begin{array}{l}\text { (Amitha et al., } \\
\text { 2012) }\end{array}$ \\
\hline Carrot & $\begin{array}{l}\text { pyrrolidine ion- } \\
\text { izes }\end{array}$ & $\begin{array}{l}N \text { atom acquires a negative charge, and } \\
\text { the free electrons on } N \text { possess still } \\
\text { higher charge, resulting in stronger bond } \\
\text { formation at } N\end{array}$ & & Alkaline & $\begin{array}{l}\text { (Amitha et al., } \\
\text { 2012) }\end{array}$ \\
\hline Black Pepper & $\begin{array}{l}\text { alkaloid "Piper- } \\
\text { ine". }\end{array}$ & $\begin{array}{l}\text { Mixed-type inhibitor and that charge } \\
\text { transfer controls the corrosion process. }\end{array}$ & mild steel & $\mathrm{HCl}$ & $\begin{array}{l}\text { (Amitha et al., } \\
\text { 2012) }\end{array}$ \\
\hline Fennel Seeds & $\begin{array}{l}\text { limonene } \\
\text { (20.8\%) and pi- } \\
\text { nene (17.8\%). }\end{array}$ & Adsorption on the metallic surface. & carbon steel & $\begin{array}{l}1 \mathrm{M} \\
\mathrm{HCl}\end{array}$ & $\begin{array}{l}\text { (Amitha et al., } \\
\text { 2012) }\end{array}$ \\
\hline Soya Bean & $\begin{array}{l}\text { hydroxy aro- } \\
\text { matic com- } \\
\text { pound }\end{array}$ & Form complexes with metals. & & & $\begin{array}{l}\text { (Amitha et al., } \\
\text { 2012) }\end{array}$ \\
\hline $\begin{array}{l}\text { Allium Cepa } \\
\text { (Onion) }\end{array}$ & Quercetin & $\begin{array}{l}\text { Adsorption site on the surface of the } \\
\text { metal }\end{array}$ & Aluminium & $\begin{array}{l}\text { Waste } \\
\text { water }\end{array}$ & $\begin{array}{l}\text { (Sulaiman et } \\
\text { al.2012) }\end{array}$ \\
\hline Orange peel & $\begin{array}{l}\text { Butyric acid, 2- } \\
\text { bromo-, 1- } \\
\text { methylethyl es- } \\
\text { ter }\end{array}$ & $\begin{array}{l}\text { Adsorption site on the surface of the } \\
\text { metal }\end{array}$ & Mild steel & $\mathrm{HCl}$ & $\begin{array}{l}\text { (Nazanin et al., } \\
\text { 2016) }\end{array}$ \\
\hline
\end{tabular}

Again, Quraishi et al., (2011) demonstrated performance of calcium stearate as inhibitor. They embedded carbon steel on ordinary portland cement standard IS: 456-2000. The results showed that inhibitor efficiencies were achieved at $90 \%$ and $93 \%$ at the concentration of $3 \%$ and $5 \%$ respectively in 60 days experiments using 3.5\% $\mathrm{NaCl}$. In line with previous study, this inhibitor reduced corrosion rate of steel by blocking concretes porous to limit ingression of chloride ions.

Joshua et al., (2015) characterized phyllanthus muellerianus as inhibitor for reducing concrete steel-reinforcement corrosion in industrial environment. They used $0.5 \mathrm{M}$ of $\mathrm{H}_{2} \mathrm{SO}_{4}$ medium to simulate industrial/microbial environment. At the concentration of $6.67 \mathrm{~g} / \mathrm{l}$, this inhibitor reduced corrosion rate of rebar to $90 \%$. While at the concentration of $1.67 \%$, the reducing corrosion rate was $78 \%$. From investigation, leaves of phyllanthus muellerianus and euphorbiaceae contained constituents which were tannins, phlobatanins, saponins, flavooids, terpenoids and alkanoids. P. muellerianus.

Abbas et al., (2018) investigated effectiveness of green inhibitor extracted from waste of orange peel. They extracted dry orange peel using methanol extract at 6-hour immersion time in methanol at the pressure (60 mbar) and $40^{\circ} \mathrm{C}$. From the experimental data using electrochemical polarisation measurements and weight-loss testing for 7 days immersion time of rebar, it was showed that this inhibition showed a good performance in aqueous 3.5 wt\% $\mathrm{NaCl}$ solutions. The steel rebar showed that corrosion rates of rebar decreased to 0.02 $\mathrm{mm} /$ year at the $3 \%$ concentration of inhibitor.

Shaymaa et al., (2017), studied powdered rice husk for corrosion of steel in concrete. They added extract of rice husk to the concrete with American mix design method ( $\mathrm{ACl} 211)$ at

DOI: http://dx.doi.org/10.17509/ijost.v3i2.12760 | p- ISSN 2528-1410 e- ISSN 2527-8045 | 
the strength of $30 \mathrm{MPa}$ at age of 28 days. The samples of rebar were cured in tap water for a period 30 days with immersed in $3.5 \% \mathrm{NaCl}$ solution. Corrosion test were conducted at the solution in different concentration (1\%, $2 \%$ and $3 \%)$ of inhibitor. The data recorded that the corrosion current was $41.3 \mu \mathrm{A} / \mathrm{cm}^{2}$ for the solution without inhibitor and it become 28.5 $\mu \mathrm{A} / \mathrm{cm}^{2}$ and $7.8 \mu \mathrm{A} / \mathrm{cm} 2$ for the solution with inhibitor $1 \%$ and $3 \%$ rice husk powder, respectively. It means the reduction of corrosion rate was $30 \%$ and $81 \%$ respectively.

Loto et al., (2013) developed vernonia amygdalina (bitter leaf) as corrosion inhibitor for rebar. The rebar with chemical composition of: $0.3 \% \mathrm{C}, 0.25 \% \mathrm{Si}, 1.5 \% \mathrm{Mn}, 0.04 \% \mathrm{P}, 0.64 \% \mathrm{~S}$, $0.25 \% \mathrm{Cu}, 0.1 \% \mathrm{Cr}, 0.11 \% \mathrm{Ni}$, and the rest of $\mathrm{Fe}$, was used for the reinforcement. Four different concentrations of $25 \%, 50 \%, 75 \%$ and $100 \%$ of the extract were used. They used electrochemical potential measurement, $\mathrm{pH}$ and gravimetric (weight loss) methods. The experiments were performed using bitter leaf extract as a green inhibitor in $3.5 \%$ sodium chloride solution. Inhibitor extracts concentrations of 25, 5075 , and $100 \%$ were prepared from the fresh leaves of vernonia amygdalina with distilled water. Vernonia amygdalina extract gave good corrosion inhibition performance of the embedded steel rebar in concrete at 25\%, 50\% and $75 \%$ concentrations in $\mathrm{NaCl}$ test medium. The highest inhibition efficiency of $90.08 \%$ was achieved at $25 \%$ concentration, the lowest inhibitor concentration used. The also recorded $\mathrm{pH}$ of concrete which showed effects of vernonia Amygdalina at 25\% concentration addition at the concrete, The $\mathrm{pH}$ reduced from 10.63 - 9.04. At 50\% concentration, $\mathrm{pH}$ reduced from $10.52-9.10$.

Inhibitor extracted form leaves of bambusa arundinacea (Indian Bamboo) for rebar protection was under investigated (Gouda, 1970). Ordinary Portland Cement (OPC) was used in this research. The concretes were mixed with chloride concentrations of $0.94 \%$. The water content was kept constant to 230 $\mathrm{kg} / \mathrm{m}^{3}$. The water-cement ratio $(\mathrm{w} / \mathrm{c})$ used was 0.45 . The fresh density of concrete was then obtained as per guidelines specified by British method of mix selection (DOE) to be $2380 \mathrm{Kg} / \mathrm{m}^{3}$. Corrosion tests were carried out after 180 days of exposure of wet and dry cycles. From the data, bambusa arundinacea extract reduced corrosion rate of rebar to $1.53 \mathrm{x}$ $10^{-3}$ as calculated using EIS and LPR methods. Compared without inhibitor, corrosion rate of rebar was $2.169 \times 10^{-3}$ (EIS) and $1.8 \times 10^{-3}$ (LPR) which means that there was an efficiency of $72 \%$. The results of LPR and EIS also showed that the concrete resistivity (Rc) and polarization resistance (Rp) values increased as bambusa arundinacea was added.

Lisha et al., (2017) used azadirachta indica (neem) powder and dehydrated aloe vera as corrosion inhibitor for steel in concrete. M 25 grade concrete was used with coarse aggregates of $20 \mathrm{~mm}$ size. The concrete was immersed in solution with salinity of about 3.5\% (35 g/L). The concrete with green corrosion of neem inhibitors have reduced corrosion rate of steel on concrete from $0.3 \mathrm{~mm} / \mathrm{y}$ to 0.22 $\mathrm{mm} / \mathrm{y}$. Inhibitor of aloe vera extract showed that the corrosion rate reduced to $0.27 \mathrm{~mm} / \mathrm{y}$. The results of inhibitors showed that azadirachta indica (neem) has better corrosion inhibition efficiency compared to the aloe vera inhibitor.

Akshatha et al., (2015) did studies on inhibitor with leaves of ruta graveolens and azadirachta. The extracted leaf of azadirachta indica (neem) and ruta graveolens plants were used as organic inhibitors. They compared with inorganic inhibitor which was sodium nitrate and ethylene diaminetetra acetic (EDTA) disodium dihydrate. The inhibitors were added during mixing of concrete and the reinforcing steel bar. The concrete was made of cement of OPC 43 grade with specific gravity 3.279 . The

DOI: http://dx.doi.org/10.17509/ijost.v3i2.12760 | p- ISSN 2528-1410 e- ISSN 2527-8045 | 
rebar were immersed in the hydrochloric acid $(\mathrm{HCl})$, sodium chloride $(\mathrm{NaCl})$ and magnesium sulphate $\left(\mathrm{MgSO}_{4}\right)$ solution for corrosion test. From half cell potential measurement, experimental in $5 \% \mathrm{HCl}$ for 56 days, it can be seen that extracts of azadirachta Indica have shown the most positive potential which followed by ruta graveolens, sodium nitrate and EDTA disodium dihydrate. The same trend also occurred when the experiments were conducted in $5 \%$ $\mathrm{NaCl}$ solutions which showed that azadirachta Indica gave the most positive corrosion potential. On contrary happened when rebar were immersed in $5 \% \mathrm{MgSO}_{4}$ solutions, inorganic inhibitors (EDTA disodium dehydrate and sodium nitrate) showed the most positive corrosion potential.

Eyu et al. (2013) studied application of vernonia amygdalina (bitter leaf) as corrosion inhibitor for carbon steel (grade 40) reinforcing bar immersed in $3.5 \% \mathrm{NaCl}$ solution for 8 weeks immersing time. They extracted the leaf using methanol to obtain liquid inhibitor. By using cylindrical concrete block mixed with vernonia extracts, they studied corrosion rate of the rebar. The other experiments, they used sodium nitrite as inorganic corrosion inhibitor for comparison. From observation vernonia extracts contains alkaloids, saponin and tannin. Data recorded showed that sodium nitrite at $2 \% \mathrm{v} / \mathrm{v}$ in $3.5 \% \mathrm{NaCl}$ solution had corrosion rate of $0.007 \mathrm{~mm} / \mathrm{y}$ for 8 weeks immersing time. Corrosion rate of rebar without inhibitor was $0.09 \mathrm{~mm} / \mathrm{y}$. From the data, they recorded that sodium nitrite inhibitor had highest inhibition efficiency which was $96 \%$. The vernonia amygdalina inhibitor shows increased $E_{\text {corr }}$ to $+95 \mathrm{mV}$ and calcium nitrite $+85 \mathrm{mV}$ for concentration of $12 \mathrm{l} / \mathrm{m}^{3}$ within the 70 days of immersion. Further investigation, they noted that the presence of tannins, alkaloids and saponnins in vernonia amygdalina which acted as barrier for chloride ingression. Weight loss test revealed that sodium nitrite inhibitor shows higher inhibition efficiency of $96 \%$ followed by calcium nitrite with $91 \%$ for $2 \% \mathrm{v} / \mathrm{v}$ inhibitor. However, vernonia amygdalina has inhibition efficiency of $75 \%$ with $6 \% \mathrm{v} / \mathrm{v}$.

Palanisamy et al. (2016) investigated effect of prosopis juliflora extract on corrosion of steel in concrete in $3.5 \% \mathrm{NaCl}$. Corrosion test were conducted after 30 days immersion time of rebar without and with the inhibitor. From corrosion test, it was revealed that corrosion inhibitor will reach efficiency $91 \%$ at concentration of inhibitor $120 \mathrm{ppm}$. At low concentration of inhibitor (100 ppm), the efficiency was $51 \%$. From EIS studies, it was stated that there was diffusion process and precipitation effect of the solid calcium hydroxide layer for formation of a protective layer at the steel/concrete interface. Further, the increasing concentration of inhibitor will reduce surface inhomogeneity due to the adsorption of the extract molecules over the surface of the embedded steel. From AFM images, it can be seen there was absorption of inhibitors molecules to the rebar surface to form protective layer which reduced corrosion rate of the rebar.

Figure 1 shows the two-dimensional AFM images of the surface of the reinforced steel in concrete without and with the p. juliflora extract. Figure 1a shows that there was corroded surface of the steel embedded in concrete caused by chloride ions. Figure $1 \mathrm{~b}$ shows the corroded steel was protected by p. julifora extract used as inhibitor. The inhibitor forms zonal film adsorbed on embedded steel surface when the concentration of inhibitor was $100 \mathrm{ppm}$. This inhibitor also affected on surface roughness (Sa). Surface of steel without inhibitor has Sa $119 \mathrm{~nm}$ compared to 19 $\mathrm{nm}$ for steel with $100 \mathrm{ppm}$ inhibitor of $\mathrm{p}$. juliflora extract.

DOI: http://dx.doi.org/10.17509/ijost.v3i2.12760 | p- ISSN 2528-1410 e- ISSN 2527-8045 | 

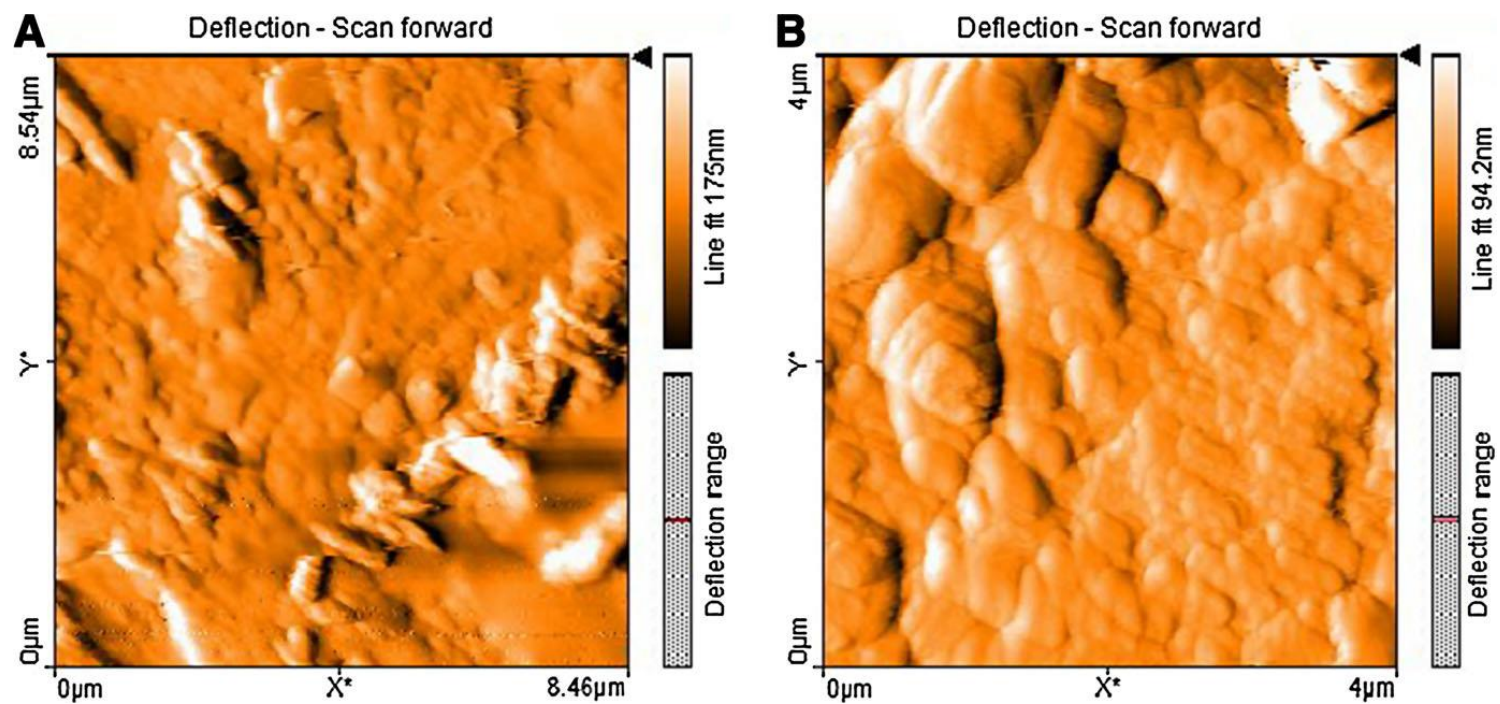

Figure 1. Ilustration of Cu-ETA complex compound (Cho et al, 2014)

\section{CONCLUSION}

Normally, inorganic/chemical inhibitors have satisfied in corrosion prevention of steels in concretes. But because of hazardous for environments, applications of these inhibitors are going to be restricted. As alternative, green corrosion inhibitors, have become a main concern in selecting inhibitor for steels in concretes. These green inhibitors meet the requirement properties of inhibitors used for steel in concretes which are low cost, compatible with concretes, non-toxic, degradable and applicable for industrial constructions. Mechanism theories of inhibitors in inhibiting corrosion process in steel rebar are by forming barrier film on the metal surface through physical and chemical reactions between steel and concretes. Thus, they prevent the diffusion of corrosive ions to the metal surface and blocking concretes porous. In addition, inhibitors can interference anodic or cathodic reactions to reduce corrosion rates. Typically, the more concentration inhibitor the thicker oxide films formed on the metal surface which increase films resistivity and improves inhibitors efficiency. Demand on eco-friendly inhibitor for steel rebar has increased significantly. From the reviews, there are evidences that the extract plants are the most possible to use as excellent corrosion inhibitors for steel rebar. However, the promising researches in the use of plants as corrosion inhibitors for rebar are still far from the ideal inhibitors which are high efficiency as inorganic/chemical inhibitors. However, it can be confidently stated that green inhibitors will continue to be used for corrosion prevention in the future with further modifications. Future improvements should combine types of inhibitors with the excellent adsorption properties and anodic or cathodic mechanism to achieve green inhibitors with the most attractive performance.

\section{ACKNOWLEDGEMENTS}

The authors are thankful to Universiti Malaysia Pahang for providing grant under RDU150372 and RDU1703322.

\section{AUTHORS' NOTE}

The author(s) declare(s) that there is no conflict of interest regarding the publication of this article. Authors confirmed that the data and the paper are free of plagiarism.

DOI: http://dx.doi.org/10.17509/ijost.v3i2.12760 | p- ISSN 2528-1410 e- ISSN 2527-8045 | 
167 | Indonesian Journal of Science \& Technology, Volume 3 Issue 2, September 2018 Hal 158-170

\section{REFERENCES}

Abbas, A.S.É.F. \& T.I.Török,. (2018). Corrosion studies of steel rebar samples in neutral sodium chloride solution also in the presence of a bio-based (green) inhibitor, Int. J. Corros. Scale Inhib., 7(1), 38-47.

Abiola, O.K.N.C.O., E. E. Ebenso, and N. M. Nwinuka. (2007). Eco-friendly corrosion inhibitors: The inhibitive action of Delonix Regia extract for the corrosion of aluminium in acidic media. Anti-Corrosion Methods and Materials, 54, 219-224

Akshatha, G.B.G.J., Kumar \& Pushpa. (2015). Effect of Corrosion Inhibitors in Reinforced Concrete. International Journal of Innovative Research in Science, Engineering and Technology. 4(8).

Alia, F.F., et al., (2017). High temperature oxidation in boiler environment of chromized steel. IOP Conference Series: Materials Science and Engineering. 257(1), 012086.

Amitha R. B. E, B.B., J. Basu., (2012). Green Inhibitors for Corrosion Protection of Metals and Alloys: An Overview. International Journal of Corrosion.

Asma, R., Y.P. Asmara, and C. Mokhtar. (2011). Study on the effect of surface finish on corrosion of carbon steel in CO2 environment. Journal of Applied Sciences, 11(11), 2053-2057.

Asmara, Y.P. A.G.M.Z.J.J., J.P. Siregar, D. Bachtiar, T. Kurniawan, Corrosion inhibition of carbon steel in oil and gas environments, International Journal of Advanced and Applied Sciences, 3 (5), 2016.

Asmara, Y.P., A. Juliawati, and A. Sulaiman. (2013). Mechanistic model of stress corrosion cracking (scc) of carbon steel in acidic solution with the presence of $\mathrm{H} 2 \mathrm{~s}$. in IOP Conference Series: Materials Science and Engineering.

Asmara, Y.P., et al., (2016) Long Term Corrosion Experiment of Steel Rebar in Fly Ash-Based Geopolymer Concrete in $\mathrm{NaCl}$ Solution. International Journal of Corrosion, 5.

Asmara, Y.P., et al., (2016). Predicting Effects of Corrosion Erosion of High Strength Steel Pipelines Elbow on CO2-Acetic Acid (HAc) Solution. IOP Conference Series: Materials Science and Engineering. 114(1), 012128.

Asmara, Y.P., et al., (2017) Development of green vapour corrosion inhibitor. IOP Conference Series: Materials Science and Engineering, 257(1), 012089

Asmara, Y.P., et al., (2017). Application of response surface methodology method in designing corrosion inhibitor. IOP Conference Series: Materials Science and Engineering. 257(1), 012090.

Asmara, Y.P.a.M.I., (2011). Study combinations effects of HAc in H2S/CO2 corrosion. Journal of Applied Sciences, 11(10), 1821-1826.

Bentur, A., Diamond, Sidney, Berke, S. Neal. (1997) Steel Corrosion in Concrete: Fundamentals and civil engineering practice. Modern Concrete Technology, 201.

Bertolini, F.B. \& T. Pastore. (2013). Behaviour of stainless steel in simulated concrete pore solution. British corrosion journal, 218-222. 
Bhawsar, J.J., (2015). Experimental and computational studies of Nicotiana tabacum leaves extract as green corrosion inhibitor for mild steel in acidic médium. Engineering Journal. 54, 769-775.

Cabrini, M.F.F., S. Lorenzi, T. Pastore, \& S. Pellegrini. (2015). Effect of Organic Inhibitors on Chloride Corrosion of Steel Rebars in Alkaline Pore Solution. Journal of Chemistry, 521507.

Cabrini, M.T.P. (2002). Effect of chemical substances on localized corrosion of steel in alkaline environments and concrete. in Frontiers in Corrosion Science and Technology: Proceedings of 15th International Corrosion Congress, Granada, 22-27, 2481-2488,

Darwin D, J.A.B., M. O’Reilly \& L. Xing. (1974). Critical Chloride Corrosion Threshold for Galvanized Reinforcing Bars, A Report on Research Sponsored by the International Lead Zinc Research Organization, Inc. Project Code - ZC-24-2.

Ebenso, E.E.U.J.I., U. J. Ekpe et al. (2004). Corrosion inhibition studies of some plant extracts on aluminium in acidic medium, Transactions of the SAEST, 39(4), 117-123.

Elsener, B. (2001). Corrosion Inhibitors for Steel in Concrete: State of the Art Report,. EFC Publications, 35.

Eyu, D.H.E., C. Chukwuekezie, J. Idris, \& Mohammad. (2013). Effect of Green Inhibitor on The Corrosion Behaviour of Reinforced Carbon Steel in Concrete. ARPN Journal of Engineering and Applied Sciences, 8(5).

Freire, L. X.R.N., M. F. Montemor, and M. J. Carmezim. (2009). Study of passive films formed on mild steel in alkaline media by the application of anodic potentials. Materials Chemistry and Physics, 114(2-3), 962-972.

Gaidis, J.M., (2004). Chemistry of corrosion inhibitors. Cement and Concrete Composites, 26(3), 181-189.

García Alonso, M.L.E., \& J.M.Mirandaa. (2007). Corrosion behaviour of new stainless steels reinforcing bars embedded in concrete, Cement and Concrete Research. 37(10), 14631471.

Gouda, V.K, W.Y.H., (1970). Corrosion and Corrosion Inhibition of Reinforced Steel, Brit. Corrosion Journal, 5, 204-208

Gouda, V.K., (1970). Corrosion and corrosion inhibition of reinforcing steel. I. Immersed in alkaline solutions. British Corrosion Journal. 5(5), 198-203.

Hausmann, D.A. (1967). Steel corrosion in concrete-how does it occur? MAterials Protection. 6(11), 19-23.

Hazwan, M.H., A.A. Rahim, M. Nasir, and M. Ibrahim. (2016). The capability of ultra filtrated alkaline and organosolv oil palm (Elaeis guineensis) fronds lignin as green corrosion inhibitor for mild steel in $0.5 \mathrm{M} \mathrm{HCl}$ solution, Measurement, 78, 90-103

Hope, B.B. (1987). Chloride Corrosion Threshold in Concrete. ACl Mater, 306-314.

Hurley, M.F, J.R.S. (2006). Threshold Chloride Concentrations of Selected Corrosion-Resistant Rebar Materials Compared to Carbon Steel. Corrosion Science, 62, 892-904. 
169 | Indonesian Journal of Science \& Technology, Volume 3 Issue 2, September 2018 Hal 158-170

Jae Kim, M.K.K. \& K. Yong Ann. (2016). The Influence of C3A Content in Cement on the Chloride Transport, Advances in Materials Science and Engineering.

James, M.G. (2004). Chemistry of corrosion inhibitors, Cement \& Concrete Composites, 26, 181-189.

Jennifer L. Kepler, D.D., Carl E. Locke, Jr., (2000) Evaluation of Corrosion Protection Methods for Reinforced Concrete Highway Structures Structural Engineering and Engineering Materials SM Report No. 58, UNIVERSITY OF KANSAS CENTER FOR RESEARCH, INC. LAWRENCE, KANSAS.

Joshua, O.A.O., \& O. Olubanke. (2015). Investigating prospects of Phyllanthus muellerianus as ecofriendly/sustainable material for reducing concrete steelreinforcement corrosion in industrial/microbial environment. Energy Procedia. 74, $1274-1281$.

Kumar, V.R.S., and M. A. Quraishi., (2013). A Study on Corrosion of Reinforcement in Concrete and Effect of Inhibitor on Service Life of RCC. J. Mater. Environment Science, 4(5), 726731.

Lisha, C.M.R., \& G. Sunilaa. (2017). Corrosion Resistance of Reinforced Concrete with Green Corrosion. International Journal of Engineering Science Invention Research \& Development; 3(11).

Loto, C.A, O.O.J., R.T. Loto, \& A.P.I. Popoola. (2013). Inhibition Effect of Vernonia amygdalina Extract on the Corrosion of Mild Steel Reinforcement in Concrete in $3.5 \mathrm{M} \mathrm{NaCl}$ Environment. Int. J. Electrochem. Sci., 8,11087 - 11100.

Magdalena, O.D.W., (2016). Organic substances as corrosion inhibitors for steel in concrete an overview. Journal of Building Chemistry, 1, 42-53.

Nazanin, B. A.G., Salahandish, Effect of Orange Peel Extract on the Corrosion of Mild Steel in 1 M HCl Solution, 6th Conference on Thermal Power Plants, CTPP 2016 19-20 Jan. 2016, Iran University of Science and Technology, Tehran, Iran.

Njokua, D.M.A \& Chidiebere, K.I.O., (2013). Corrosion inhibition of mild steel in hydrochloric acid solution by the leaf extract of Nicotiana tabacum. Adv Mater Corros. 1, 54-61.

Ormellese, M.M.B, F. Bolzoni, and T. Pastore. (2006). Corrosion inhibitors for chlorides induced corrosion in reinforced concrete structures. Cement and Concrete Research, 36(3), 536547

Page, C.L., (1975). Mechanism of corrosion protection in reinforced concrete marine structures. Nature, 258(5535), 514-515.

Palanisamy, S.P.G.M., C. Kamal, \& G. Venkatesh. (2016). Prosopis juliflora-A green corrosion inhibitor for reinforced steel in concrete. Research on Chemical Intermediates. 42(12), 7823-7840

Petterson, K. R.N.S. (1994). Chloride Threshold Value and the Corrosion Rate in Reinforced Concrete. Proceedings of the International Conference on Corrosion Protection of Steel in Concrete, Academic Press, Sheffield, 461. 
Quraishi, M.A.V.K., B.N. Singh \& S.K. Singh. (2012). Calcium Palmitate: A Green Corrosion Inhibitor for Steel in Concrete Environment. J. Mater. Environ. Sci. X(6), 1001-1008, 20282508 .

Quraishi,M.A, D.K.Y.,and I. Ahamad. (2009). Green approach to corrosion inhibition by black pepper extract in hydrochloric acid solution. Open Corrosion Journal, 2, 56-60.

Quraishi,M.A.V.K., P.P. Abhilash \& B.N. Singh. (2011). Calcium Stearate: A Green Corrosion Inhibitor for Steel in Concrete Environment. J. Mater. Environ. Sci. 2(4), 365-372, ISSN : 2028-2508.

Rosenberg, A.C.M.H.,\& C. Andrade. (1989). Mechanisms of corrosion of steel in concrete, Materials science of concrete. The American Ceramic Society, 285-313.

Sangeetha M, S.R., T. Muthumegala, A. Krishnaveni. (2011). Green corrosion inhibitors-An Overview. Department of Chemistry (S\&H), K.S.Rangasamy College of Technology,Tiruchengode,Tamil Nadu, India.

Sastri, V.C.i.P.A., John Wiley \& Sons. (2001). UK, 619.

Shahid, M. (2011). Corrosion protection with eco-friendly inhibitors. Adv. Nat. Sci.: Nanosci. Nanotechnol, 2(04), 3001.

Shaymaa, A., Ali I. Al-Mosawi, Ali Amer \& A. Hadi. (2017). Studying the Effect of Eco-addition Inhibitors on Corrosion Resistance of Reinforced Concrete. Bioprocess Engineering, 1(3): 81-86.

Söylev, T.A \& M.G.R., (2008). Corrosion inhibitors for steel in concrete: state-of-the-art report. Construction and Building Materials, 22(4), 609-622.

Sulaiman, N.-A., \& Abd-Razak. (2012). A Study of Using Allium Cepa (Onion) as Natural Corrosion Inhibitor in Industrial Chill Wastewater System. Research Journal of Chemical Sciences, 2231-606X, 2(5), 10-16.

Valcarce, M.V., (2008). Carbon steel passivity examined in alkaline solutions: the effect of chloride and nitrite ions. Electrochimica Acta, 53(15), 5007-5015.

Vermani, J., L. Kepler, D. Darwin, E. Carl E. Locke, Jr. Virmani, Y. P. Clear, K. C. and Pasko., (1983). Evaluation of Corrosio Protection Methods for Reinforced Concrete Highway Strcuture "Time to Corrosion of Reinforcing Steel in Concrete Slabs-Calcium Nitrite Admixture or Epoxy Coated Reinforcing Bars as Corrosion Protection Systems, Report No. FHWA-RD83012, Federal Highway Administration, Washington, D.C. 